This article has been published in a revised form in Legal Studies, http://doi.org/10.1017/lst.2018.27. This version is published under a Creative Commons CC-BY-NC-ND. No commercial re-distribution or re-use allowed. Derivative works cannot be distributed. (C) copyright holder.

\title{
A Dish Served Cold: Targeting Revenge in Revenge Pornography
}

\section{Abstract:}

The introduction of Section 33 of the Criminal Justice and Courts Act 2015, criminalising the disclosure of private sexual images, has been seen as a welcome step forward for curbing this abuse of privacy and the harmful effects it has on victims. However, while Section 33 sidesteps any reference to 'revenge pornography', as the phenomenon has been termed in popular vernacular, little attention has been paid to the way in which narratives of revenge implicitly underpin and imbue the new offence, particularly its specific intent requirement. We argue this has serious implications for the treatment of Section 33 offences in the courts and for sentencing. Drawing on cross-disciplinary conceptualisations of revenge, its recent criminal-legal history, and examples of media and parliamentary rhetoric, we claim that despite innumerable attempts to turn debate on disclosure of private sexual images towards consent, harm and privacy, there lurks within these discourses an assumption that the victim must have done something to deserve the treatment she received. Until the multiple harms of disclosure of private sexual images are recognised and explicit recommendations are made that scrutiny of victims' behaviour should normally be inadmissible, we argue that the offence offers little in the way of redress. 
This article has been published in a revised form in Legal Studies, http://doi.org/10.1017/lst.2018.27. This version is published under a Creative Commons CC-BY-NC-ND. No commercial re-distribution or re-use allowed. Derivative works cannot be distributed. (C) copyright holder.

\section{Introduction}

In 2015, Section 33(1) of the Criminal Justice and Courts Act 2015 made it an offence to disclose a private sexual photograph or film if the disclosure is made:

(a) without the consent of an individual who appears in the photograph or film, and

(b) with the intention of causing that individual distress.

The strengths and weaknesses of the new offence in terms of scope and reach have been well documented. Gillespie is particularly critical of the specific mens rea requirement that a perpetrator's object is to cause distress, ${ }^{1}$ while McGlynn and Rackley, and Henry and Powell have argued that the focus on 'revenge pornography' fails to take into account other forms of 'image-based sexual abuse. ${ }^{2}$ Citron and Franks have also outlined in some detail potential justifications for criminal-legal intervention, ${ }^{3}$ and the definition of 'pornography' in the context of revenge pornography has been contested. ${ }^{4}$ However, little attention has yet been paid to the specifics of why the offence in England and Wales is narrow. Despite the fact that Section 33 makes no explicit mention of revenge, our contention is that socio-cultural scripts of revenge nevertheless underpin the debates that shaped the offence, and will inform the treatment of the offence in the courts. By

\footnotetext{
${ }^{1}$ A Gillespie “"Trust Me, It's Only for Me”: Revenge Porn' and the Criminal Law' (2015) Crim L Rev 866.

2 C McGlynn and E Rackley 'Image-Based Sexual Abuse' (2017) Oxford J Legal Stud DOI: 10.1093/ojls/gqw033; N Henry and A Powell 'Sexual Violence in the Digital Age: The Scope and Limits of Criminal Law’ (2016) 25 Soc and Legal Stud 397.

${ }^{3}$ D K Citron and M A Franks 'Criminalizing Revenge Porn' (2014) 49 Wake Forest L Rev 345.

${ }^{4}$ Henry and Powell, above, n 2.
} 
This article has been published in a revised form in Legal Studies, http://doi.org/10.1017/lst.2018.27. This version is published under a Creative Commons CC-BY-NC-ND. No commercial re-distribution or re-use allowed. Derivative works cannot be distributed. (C) copyright holder.

engaging with the meanings attributed to revenge and its recent criminal-legal history, we address the question of why it is that revenge pornography above other forms of technology-facilitated sexual violence ${ }^{5}$ has so fervently captured the popular imagination, proven such effective tabloid fodder, and elicited more commentary, debate, and campaigning for criminalisation than other forms of gendered violence in recent years. ${ }^{6} \mathrm{We}$ will argue that despite many attempts to turn the debate on revenge pornography towards consent, harm and privacy, it is the revenge narrative that proves to be the principal rhetoric that underpins justifications for criminalisation, the focus in calls for early reform of the law and sentencing guidelines, and the mainstay of media reporting. ${ }^{7}$

The origins of the term revenge pornography can be traced back to media stories concerning Hunter Moore and the infamous 'isanyoneup' website. Hunter Moore became one of the first individuals prosecuted for the sharing of private sexual images without consent. While the offence for which Hunter Moore was eventually imprisoned amounted to identity theft ${ }^{8}$ and unauthorised access to a computer, the term 'revenge pornography', which emerged in his case, remained and has shaped media coverage since. In England and Wales one of the first widely publicised instances of revenge pornography concerned Tulisa

\footnotetext{
${ }^{5}$ N Henry and A Powell 'Embodied Harms: Gender, Shame, and Technology-Facilitated Sexual Violence' (2015) 21 Violence Against Women 758.

${ }^{6}$ The long-standing but comparatively underreported phenomenon of up-skirting, for example, has until recently been superseded - indeed eclipsed entirely - in the wake of the 'discovery' of revenge pornography. Over the last few months, a campaign was launched to target up-skirting in England and Wales via an amendment to S 67 Sexual Offences Act 2003, and it was raised for the first time in oral questions in the House of Commons on $5^{\text {th }}$ September 2017 (HC Deb, 5 September 2017, vol 628, col 12). However, no legislative action has yet been taken.

7 While there are, of course, other 'backstories' that underpin the new offence, such as cyberbullying and cyberstalking, these are rarely foregrounded in either parliamentary debate on the construction of the offence or its reform, or in media reporting on the case law.

8 'Revenge porn website operator Hunter Moore sentenced to 30 months in prison', The Verge (3 October 2015), see http://www.theverge.com/2015/12/3/9843038/hunter-moore-revenge-porn-isanyone-up-prison-sentence (accessed 3 November 2017).
} 
This article has been published in a revised form in Legal Studies, http://doi.org/10.1017/lst.2018.27. This version is published under a Creative Commons CC-BY-NC-ND. No commercial re-distribution or re-use allowed. Derivative works cannot be distributed. (C) copyright holder.

Contostavlos (previously of N-Dubz fame). The incident predated the introduction of Section 33, instead utilising civil litigation. However, the facts of the case are illustrative of most revenge porn cases; Tulisa's ex-boyfriend posted the images following the breakup of their relationship mirroring many reported cases of revenge pornography. Thus, 'revenge pornography' may be a media constructed term, but we argue that it is this particular narrative, and set of gendered characterisations, that became the paradigmatic story around which the legality of disclosure of private sexual images was debated.

The paradigmatic story of the revenge pornography scenario is thus as follows: a woman shares with her partner erotic images of herself, or permits those pictures to be taken. She then leaves her partner. Said ex-partner goes on to share these intimate and often explicit images, taken with consent, either on social media platforms or on specifically targeted revenge pornography websites, such as MyEx.com, and the now-defunct IsAnyoneUp, without consent. The image is sometimes discovered at this point, or worse, as a result of dissemination to other websites. In many cases, victims have reported harassment and stalking, the circulation of their private addresses and contact details online, and often retreat from public spaces on and offline as a result of this assault on their privacy, in addition to experiencing considerable distress. ${ }^{9}$

There is also a parallel debate surrounding revenge motives in the context of 'crimes of passion', usually violence against women, and usually perpetrated by intimate partners when a relationship ends, or where there is suspicion of

\footnotetext{
${ }^{9}$ For case studies, see Citron and Franks, above n 3; M Salter and T Crofts 'Responding to Revenge Porn: Challenges to Online Legal Impunity' in L Cormella and S Tarrant (eds) New Views on Pornography: Sexuality, Politics, and the Law (Praeger Press, Santa Barbara, CA: 2015) pp 233-256.
} 
This article has been published in a revised form in Legal Studies, http://doi.org/10.1017/lst.2018.27. This version is published under a Creative Commons CC-BY-NC-ND. No commercial re-distribution or re-use allowed. Derivative works cannot be distributed. (C) copyright holder.

adultery. As Howe has documented, ${ }^{10}$ revenge as gender-based violence has previously emerged most frequently in cases of spousal homicide. ${ }^{11}$ Like Howe, we adopt the term 'crime of passion' to describe not merely an act of violence that takes place without premeditation, but to denote the context in which it takes place, and how this frames the way in which it is viewed as unpremeditated: romantic intimacy. We view revenge pornography, then, as a contemporary means of orchestrating 'crimes of passion', in which new technologies are weaponised against deviation from romantic virtue, usually against women. While there has been controversy over the term 'pornography' being attached to these images, ${ }^{12}$ we argue that the phenomenon represents the shaping of an explicit image to the terms of the pornographic specifically to exact revenge on the party depicted, and thus use the term 'revenge pornography' throughout this piece. Within the relevant sections discussing the offence the phrase 'disclosure of private sexual images' is used to distinguish the letter of the law from popular parlance.

We begin by examining attempts to conceptualise revenge to better understand what is at stake in the debates about the need for the offence, and the way in which it is being operationalized, and then provide a legal backdrop that outlines the debates surrounding the introduction of the new offence. We then trace how revenge has been treated historically in English criminal law, specifically in the context of 'crimes of passion'. We argue that the legal response to 'crimes of passion' has crucial implications for revenge pornography cases, and

\footnotetext{
${ }^{10}$ A Howe 'Provoking Polemic - Provoked Killings and the Ethical Paradoxes of the Postmodern Feminist Condition' (2002) 10 Feminist Legal Stud 39; A Howe "“Red Mist" Homicide: Sexual Infidelity and the English Law of Murder (Glossing Titus Andronicus)' (2013) 33 LS 407.

${ }^{11}$ See, for example, $R v$ Clinton, Parker and Evans [2012] Crim 2.

${ }^{12}$ Henry and Powell, above n 2.
} 
This article has been published in a revised form in Legal Studies, http://doi.org/10.1017/lst.2018.27. This version is published under a Creative Commons CC-BY-NC-ND. No commercial re-distribution or re-use allowed. Derivative works cannot be distributed. (C) copyright holder.

that both seemingly individualise violence against women, reimagining that violence as an act of revenge with justificatory or excusatory qualities that limit wrongfulness. This leads to a discussion about our concerns that revenge may be construed implicitly as the underlying rationale for Section 33's requirement of specific intent. Specifically, without the prosecution team's provision of a backstory, where the actions of the victim and what she did to 'deserve' the actions of the perpetrator are called into question, we suggest that a finding of intention to cause distress is likely to be difficult. Finally, we argue that the terms of the original debates over criminalisation in Parliament and subsequent attempts to reform the offence, and current sentencing guidelines, are also reliant on revenge motives to determine the shape of the offence and the terms of sentence. Ultimately, we argue that the offence will remain limited until there is closer attention paid to the harms revenge pornography may cause, and debate is refocused on the broader implications of 'disclosing private sexual photographs and films with intent to cause distress', rather than the paradigmatic narrative that accompanies discussions of 'revenge pornography', and make some practical recommendations for reform.

\section{Conceptualising Revenge}

While doubt has been cast over the extent to which revenge pornography can legitimately be considered a 'new' phenomenon, ${ }^{13}$ narratives of revenge, which proved particularly persuasive in arguments for criminalisation within media rhetoric and Parliament, are by no means new. As we have noted, Section

\footnotetext{
${ }^{13}$ S H Scheller 'A Picture Is Worth a Thousand Words: The Legal Implications of Revenge Porn' (2014) 93 North Carolina L Rev 551.
} 
This article has been published in a revised form in Legal Studies, http://doi.org/10.1017/lst.2018.27. This version is published under a Creative Commons CC-BY-NC-ND. No commercial re-distribution or re-use allowed. Derivative works cannot be distributed. (C) copyright holder.

33 does not itself hinge on revenge as a form of specific intent. Nevertheless, the disclosure of private sexual imagery has continually been constructed in popular discourse as an act of revenge in response to the actions of the victim prior to the disclosure of the image. Calls for criminalisation were often reliant on this narrative to make a persuasive case for new legislation. ${ }^{14}$ The need to understand why someone might intend to cause distress through disclosure of sexual images has bled through into official discourses that do have a purchase on reform of the law and sentencing. With this in mind, it is important to consider precisely what are meant by revenge motivations, and what this can tell us about the potential problems with hinging the offence on specific intent to cause distress.

In punishment theory, most retributivists steer well clear of revenge, and tend to assert that it has no role to play in contemporary criminal law. ${ }^{15}$ Nevertheless, historically, revenge has often been positioned as precisely the target of retributive justice. Histories of revenge tend to take one of two trajectories. On the one hand, legal historians argue that the cyclical terror of blood revenge died naturally as law evolved, replacing a thirst for vengeance first with compensatory 'pounds of flesh', and then the rule of law. ${ }^{16}$ In this account,

\footnotetext{
${ }^{14}$ See for example, M A Franks and D Citron, 'It's simple: Criminalise revenge porn, or let men punish women they don't like' The Guardian 17 April 2014, available at https://www.theguardian.com/commentisfree/2014/apr/17/revenge-porn-must-be-criminalizedlaws (accessed 1 March 2018).

${ }^{15}$ For perhaps the most well-known attempt to distinguish revenge and retribution, see $\mathrm{R}$ Nozick Philosophical Explanations (Cambridge, MA: Harvard University Press, 1981). More recently, scholars such as G Fletcher (Rethinking Criminal Law (Cambridge: Cambridge University Press, 2000)) and Moore (Placing Blame: A Theory of Criminal Law (Oxford: Oxford University Press, 1997)) have provided further justification for distinguishing the two concepts. However, see T Rosenbaum's Payback: The Case for Revenge (London: University of Chicago Press, 2013) for a defence of revenge as an operative principle in the criminal justice system and indeed, drawing on the example of 'crimes of passion', an argument that it already plays a significant role.

${ }^{16}$ This perspective emerged in $19^{\text {th }}$ century legal historical works. See, for example, F Pollock and F W Maitland History of English Law Before the Time of Edward I (2nd edition, Liberty Fund Inc, 2009).
} 
This article has been published in a revised form in Legal Studies, http://doi.org/10.1017/lst.2018.27. This version is published under a Creative Commons CC-BY-NC-ND. No commercial re-distribution or re-use allowed. Derivative works cannot be distributed. (C) copyright holder.

revenge is positioned as a culturally and historically primitive response to feeling that one has been wronged, which eventually suffered from 'obsolescence and inadaptability'. ${ }^{17}$ An anathema to the development of the rule of law, to succumb to vengeful urges in the present is suggestive of a human regressiveness that must be quashed at all costs.

On the other hand, contractarian political theorists argue that it is not so simple as revenge 'dying out' with the miraculous evolution of human progress; rather, the urge for revenge exists just as it always did, but must be consciously, continually defeated, suppressed and punished by more measured forms of statesanctioned retribution. ${ }^{18}$ Furthermore, this function of law is deemed necessary precisely to "contain and metabolize" ${ }^{19}$ the revenge impulse at a socio-cultural level. Schoenfield's essay on the necessity of retribution in law suggests that if people lose faith in law's ability to deliver justice, they will be drawn into escalating patterns of personal revenge. ${ }^{20}$ Thus, the law is seen in this more utilitarian purview as not merely punishing vengeful acts, but actively preventing them by allowing such impulses to be satisfied vicariously. The distinction between retribution and revenge, and the role of revenge in the criminal justice system, is not the substance of this article, but legal theorists who promote the

\footnotetext{
${ }^{17}$ W Miller 'Clint Eastwood and Equity: Popular Culture's Theory of Revenge' in A Sarat and T Kearns (eds) Law in the Domains of Culture (Ann Arbor, MI: University of Michigan Press, 1998) p 161.

${ }^{18}$ This perspective originates with T Hobbes The Elements of Law Natural and Politic. Part I: Human Nature; Part II: De Corpore Politico with Three Lives: Human Nature Pt. 1 (Oxford: Oxford University Press, 2008).

${ }^{19}$ I C Rosen 'Revenge - the Hate That Dare Not Speak Its Name: A Psychoanalytic Perspective' (2007) $55 \mathrm{~J}$ of the American Psych Ass 595 at 607.

${ }^{20} \mathrm{C}$ G Schoenfeld 'In defense of retribution in the law' (1966) 35 Psych Quart 108.
} 
This article has been published in a revised form in Legal Studies, http://doi.org/10.1017/lst.2018.27. This version is published under a Creative Commons CC-BY-NC-ND. No commercial re-distribution or re-use allowed. Derivative works cannot be distributed. (C) copyright holder.

idea of a distinction ${ }^{21}$ tend to argue that the achievement of vengeance - once moved into the hands of the state - is justifiable and 'healthy', while when the 'law' is taken into one's own hands it is not.

In a recent overview of the psychological literature on revenge, Grobbink et al argue for a more balanced account of revenge, suggesting that a distinction cannot be made between 'healthy' and 'pathological' revenge in clinical practice, and that its constitution and function are entirely reliant on the coping style and personality of the avenger. ${ }^{22}$ In this literature, revenge is considered a 'pursuit', which develops as a result of $\operatorname{strain}^{23}$ and the distortion of self-image of the grandiose self. While we adopt a certain cynicism about the extent to which revenge thrives simply as a matter of cognitive distortions entirely divorced from cultural context, the implication here is that a vicarious enjoyment of revenge, when criminal justice produces a satisfactory result, is regarded as 'healthy', and thus has a utility. Indeed, Frijda suggests that society should not deny or condemn the desire for revenge, since the pursuit itself may - when taken 'healthily' restore psychological balance. ${ }^{24}$ In this vein, Posner posits that, in the past, people endowed with an instinct to retaliate would have tended to be more successful in struggles for survival and the urge for revenge survives as an evolutionary 'supplement' to law enforcement. ${ }^{25}$ In other words, in this model revenge is still very much alive, and considered a 'natural' and universal urge that the criminal

\footnotetext{
${ }^{21}$ See, for example, L Zaibert 'Punishment and Revenge' (2006) 25 L and Phil 81; Nozick, above n 15.

${ }^{22}$ L H Grobbink J J L Derksen and H J C van Marle, 'Revenge: An Analysis of Its Psychological Underpinnings' (2015) 59 Int J of Offender Therapy and Comparative Crim 892.

${ }^{23}$ R Agnew 'Foundation for a General Strain Theory of Crime and Delinquency' (1992) 30 Criminology 47.

${ }^{24}$ N H Frijda The Laws of Emotion (Hove: Routledge, 2007).

${ }^{25}$ R A Posner Law and Literature (Cambridge, MA: Harvard University Press, 3rd edition, 2009) $\mathrm{p} 79$.
} 
This article has been published in a revised form in Legal Studies, http://doi.org/10.1017/lst.2018.27. This version is published under a Creative Commons CC-BY-NC-ND. No commercial re-distribution or re-use allowed. Derivative works cannot be distributed. (C) copyright holder.

law has a role to play in mitigating through 'measured' means. Due process, as Sarat remarks, has the power to 'discipline passion'. ${ }^{26}$

We might also locate psychoanalytic explanations for vengeance in this second history of revenge's relationship with the law, where it is argued that revenge is envisioned as an ahistorical, asocial and narcissistic ${ }^{27}$ will-to-power that must be repeatedly defeated by recourse to the rational authority of the state and its ability to suppress it. As Beattie puts it, '[t]he high-octane jet fuel of revenge is narcissistic rage, occasioned by humiliating attacks on the grandiose self with its idealized self-object, which result in a primitive drive for control and omnipotence through revenge'. ${ }^{28}$ All id and no superego, here revenge is considered a symptom of pathological narcissism, ${ }^{29}$ where the avenger is seeking to eliminate an uncomfortable or painful emotion by restoring equilibrium.

To date, what is missing from either psychological accounts of revenge or legal scholarship on the vengeful properties of criminal law, however, is any sense of the gendered or erotic dimensions of revenge, or how the context of intimate relationships shapes its constitution and method. Durkheim suggests that the urge to punish is itself a "passionate reaction' 30 to the violation of socially constructed rules, and we are interested here in unearthing how the

\footnotetext{
${ }^{26}$ A Sarat When the State Kills: Capital Punishment and the American Condition (Princeton, NK: Princeton University Press, 2001) p 39.

${ }^{27}$ See, for example, H J Beattie 'Revenge' (2005) 53 J of the American Psych Ass 513; H Kohut, 'Thoughts on Narcissism and Narcissistic Rage' (1972) 27 The Psychoanalytic Study of the Child 360.

${ }^{28}$ Beattie, above $\mathrm{n} 27$, at 515 .

${ }^{29}$ On narcissism and revenge, see also R P Brown 'Vengeance Is Mine: Narcissism, Vengeance, and the Tendency to Forgive' (2004) 38 Journal of Research in Personality 576.

${ }^{30}$ E Durkheim The Division of Labour in Society (Basingstoke: Palgrave Macmillan, 2nd edition, 2013), p 85.
} 
This article has been published in a revised form in Legal Studies, http://doi.org/10.1017/lst.2018.27. This version is published under a Creative Commons CC-BY-NC-ND. No commercial re-distribution or re-use allowed. Derivative works cannot be distributed. (C) copyright holder.

criminal law attempts to grapple with the violation of the 'rules of civility' that accompany the breakdown of a romantic relationship, and in particular the ways in which it draws on gendered narratives of revenge.

A supposedly psychical drive for revenge is also not sufficient to explain the legal valorization of gendered revenge in the context of heteronormative romantic scripts, nor its consistent cultural-historical popularity. No matter which history or understanding of revenge one follows, Miller contends that it continues to operate for most of us on the periphery of our consciousness, ${ }^{31}$ occasionally aroused and quickly suppressed. Indeed, our culture often seems deeply conflicted about the moral status of revenge. While revenge is generally thought to be antithetical to law and the values of Western societies, it nevertheless retains its appeal as a 'pervasive theme in the movies [we] pay to see, TV [we] watch and novels [we] read. ${ }^{32}$ Thus, perhaps it is short-sighted to suggest that a narcissistic sense of injury is driven purely by narcissistic rage. In some cultures revenge is in fact a common and sometimes obligatory social norm, often in the context of adultery. Rather, if there is a collective cultural sense that certain personal slights require avenging, 'injecting disorder into order and ordering the internal disorder', ${ }^{33}$ then the social and legal scripts that determine 'duty', 'law' and 'justice' at the termination of romantic relationships, often resulting in 'crimes of passion', must be further examined to understand revenge pornography, and how these scripts have influenced popular and official

\footnotetext{
${ }^{31}$ Miller, above $\mathrm{n} 17$.

${ }^{32}$ A Sarat and T Kearns 'The Cultural Lives of Law' in A Sarat and T Kearns (eds), Law in the Domains of Culture (Ann Arbor, MI: University of Michigan Press 1998) p 17.

${ }^{33}$ Y Neuman 'On Revenge' (2012) 17 Psychoanalysis, Culture \& Soc'y 1.
} 
This article has been published in a revised form in Legal Studies, http://doi.org/10.1017/lst.2018.27. This version is published under a Creative Commons CC-BY-NC-ND. No commercial re-distribution or re-use allowed. Derivative works cannot be distributed. (C) copyright holder.

discourse on how disclosure of private sexual photographs should be dealt with through criminal law.

\section{The Legal Backdrop}

Section 33 emerged as an addition to a plethora of existing laws targeting technologically assisted or enabled sexual offending. ${ }^{34}$ The new offence does not criminalise all private sexual images disclosed without consent as it bites only if their distribution is intended to cause distress to the victim, providing a barrier to prosecutions against those who indirectly redistribute the images through social media or email. ${ }^{35}$ Whilst this approach to mens rea has not been followed internationally, ${ }^{36}$ to date the legal response in England and Wales has continued to uphold this specific requirement, regarding it as central to obtaining conviction. It is this aspect of the offence that we address over the course of this article.

The very enactment of a specific offence to tackle revenge pornography implies that current legal remedies are not fit for purpose as an adequate deterrent, yet it will be seen that both the new offence and most pre-existing laws are also reactive as opposed to preventative. Prior to the enactment of Section 33(1), legal action could be taken under a number of existing laws both criminal and civil. For example, criminal action under the Protection from Harassment Act 1997 or civil action for a 'breach of confidence'. Those pre-existing laws that serve a dual function, as both reactive and preventative, such as injunctions and the threat of a

\footnotetext{
${ }^{34}$ There are numerous sexually motivated offences that have benefited from the advancement of technology or indeed a product of them, including and not limited to voyeurism, child pornography, extreme pornography, stalking and harassment.

${ }^{35}$ J F Quinn and C J Forsyth 'Describing Sexual Behavior in the Era of the Internet: A Typology for Empirical Research’ (2005) 26 Deviant Behavior 191.

${ }^{36}$ For example, the US state of Minnesota criminalises the act regardless of the intention under Laws of Minnesota, Chapter 126 S.F.No. 2713 (USA)
} 
This article has been published in a revised form in Legal Studies, http://doi.org/10.1017/lst.2018.27. This version is published under a Creative Commons CC-BY-NC-ND. No commercial re-distribution or re-use allowed. Derivative works cannot be distributed. (C) copyright holder.

civil action for breach of confidence, are often limited to those victims who have the financial backing to bring such action. Further, neither of these laws cover all cases of revenge pornography and are limited in scope; harassment laws require a course of conduct ${ }^{37}$ and breach of confidence requires an obligation of confidence to exist between parties. ${ }^{38}$ Despite their shortcomings, these laws provided and still do provide an alternative basis for action in instances involving the disclosure of personal, private and sexual imagery without an individual's consent. Whilst it is not the intention of this article to highlight every shortcoming of the existing laws, an overview is essential in order to understand the location of revenge pornography law within the context of both a broader roster of laws, which demonstrates that the new offence offers little additional benefit to victims.

The primary means of prosecuting the disclosure of private sexual images prior to the new revenge pornography offence was through stalking and harassment offences. Stalking and harassment were made criminal offences with the enactment of the Protection from Harassment Act $1997 .{ }^{39}$ Section 2 makes it an offence to cause 'alarm or distress' and put 'people in fear of violence'. It is a requirement of the offence that a course of conduct is undertaken on two or more occasions resulting in a fear of violence or causing alarm or distress. Clearly the requirement for any course of conduct to be undertaken at least twice poses a problem in cases of revenge pornography. It would necessitate the disclosure of an

\footnotetext{
${ }^{37}$ Under existing harassment law in the England \& Wales a course of conduct must be undertaken on two or more occasions, which is unhelpful for victims of revenge pornography given that resulting harms can flow from a single disclosure of such an image.

${ }^{38}$ To establish a breach of confidence the information disclosed must have been imparted in such a way that imposed an obligation of confidence. This is not always the case in revenge pornography matters - most notably where an image has been obtained from someone's phone/icloud and disclosed without consent and then shared.

${ }^{39}$ Amended by the Protection of Freedoms Act 2012 to include stalking.
} 
This article has been published in a revised form in Legal Studies, http://doi.org/10.1017/lst.2018.27. This version is published under a Creative Commons CC-BY-NC-ND. No commercial re-distribution or re-use allowed. Derivative works cannot be distributed. (C) copyright holder.

image on two or more occasions before even engaging the law. However, the threat of disclosure could also be included under harassment laws, which, notably, would not be covered under the new offence. As with other pre-existing laws, stalking and harassment offences are reactive. The same issue is present when considering the new Section 33 offence, which is perhaps inevitable given that in criminal law individuals must engage in a course of conduct. However, a threat to disclose such imagery would at least be covered under the Protection from Harassment Act 1977, rendering the new offence even less effective given its focus is on the act and not the threat. Most notably, the offence offers no additional practical redress to the victims of revenge pornography, such as the cover of 'threats', and serves nothing other than a retributive function for a specific offence.

Section 1 of the Malicious Communications Act 1988 makes it a criminal offence to send another an article which is 'indecent or grossly offensive', or which 'conveys a threat, or which is false'. There is a requirement that the perpetrator intends to 'cause distress or anxiety' to the recipient. The offence covers the electronic communication of articles such as letters, writing of all descriptions, electronic communications, photographs and other images in a material form, tape recordings, films and video recordings; covering photographs in revenge pornography cases provided the terms of the offence are met. Connolly $v D P P^{40}$ considered the terms 'indecent or grossly offensive', confirming that these were to be interpreted as ordinary English words. ${ }^{41}$ The problem with this provision is that the article - in the case of revenge pornography, the photo -

40 [2007] 2 All ER 1012

${ }^{41}$ [2007] 2 All ER 1012 
This article has been published in a revised form in Legal Studies, http://doi.org/10.1017/lst.2018.27. This version is published under a Creative Commons CC-BY-NC-ND. No commercial re-distribution or re-use allowed. Derivative works cannot be distributed. (C) copyright holder.

needs to be offensive. It would require a finding that a private, sexual image, devoid of any illegal act, is indecent or grossly offensive. This presents a somewhat heteronormative outlook on sexual relationships and private sexual encounters as it would require that sexual acts or displays, considered outside existing standards of propriety, be found offensive. It is also arguable that the act of disclosure without consent is the offensive act, not the image itself. Additionally, in most cases it would not be the actual revenge pornography victim who receives the image but other parties. It would be the intended or actual recipient only who would have access to redress through this law.

In addition to criminal actions, civil actions have also been undertaken, the success of which is largely dependent on the financial status of the perpetrator and the victim, in order to bring or defend a claim. It is worth noting at this point that the new offence fails to provide a course of action against hosts of websites or commercial entities that would have the financial net worth to make a civil action worthwhile. Laws concerning copyright ${ }^{42}$ and tortious wrongs such as 'breach of confidence $^{43}$ are examples of civil actions applicable to revenge pornography cases. Copyright law in its most basic form serves as a right to prevent others from copying or reproducing the author's work. It is the expression of an idea that is protected and not the idea itself. This is especially relevant for artistic works, such as graphic works and photos, with which we are concerned here. To what extent revenge pornography images themselves can actually be regarded as artistic is fairly unambiguous given that most works of art are afforded protection

\footnotetext{
${ }^{42}$ See Part 1 of the Copyright Designs and Patents Act 1988 (CDPA) as amended, although also a criminal offence, see section 107 CDPA.

${ }^{43}$ See Duchess of Argyll v Duke of Argyll [1967] Ch 302
} 
This article has been published in a revised form in Legal Studies, http://doi.org/10.1017/lst.2018.27. This version is published under a Creative Commons CC-BY-NC-ND. No commercial re-distribution or re-use allowed. Derivative works cannot be distributed. (C) copyright holder.

irrespective of artistic quality. It is noted that some revenge pornography cases involve the victim's own photos being disseminated without their consent. Therefore, the victim is the author in this case, and the distribution (the forwarding of the image without consent) infringes copyright. The one thing that sets copyright law apart from the new Section 33 offence is the 'take down' remedy offered to those whose copyright is infringed. In theory, this would provide victims with a way of serving notices on website hosts to take images down.

Whilst copyright law may serve as a viable course of legal action in response to the disclosure of private sexual imagery, ${ }^{44}$ the restrictions placed on utilising this area of law are significant. Financially, a pursuit to challenge copyright infringement under the respective laws requires substantial financial backing, for which there is no state-sanctioned support (such as legal aid in criminal proceedings). Further, the action, as with all the laws discussed, fails to prevent unauthorised dissemination occurring. Given the nuanced nature of copyright law it is also unlikely that any potential perpetrator would be aware of it and in turn deterred by it, thus curbing the likelihood of any revenge pornography offence being committed. A further issue relates to the use of the internet in revenge pornography cases, as the complexity of any case would be largely determined by where the imagery was being hosted and by whom. This would determine which jurisdictions' copyright laws are applicable to the infringement and subsequent infringements.

\footnotetext{
${ }^{44}$ A Levendowski 'Using Copyright to Combat Revenge Porn' (2013) 3 NY University J of Intel Prop \& Ent L 422.
} 
This article has been published in a revised form in Legal Studies, http://doi.org/10.1017/lst.2018.27. This version is published under a Creative Commons CC-BY-NC-ND. No commercial re-distribution or re-use allowed. Derivative works cannot be distributed. (C) copyright holder.

Action could be taken in tort prior to the enactment of Section 33, as set out in $A v B P l c^{45}$ concerning a breach of confidence. This ruling applied in cases where confidential images are disseminated within or outside marriage. Importantly, under this action such an obligation of confidence extends to others who forward an image on. Under this law there is a duty of confidence 'whenever a person receives information he knows or ought to know is fairly and reasonable to be regarded as confidential' or in matters where it is clearly of a private nature. ${ }^{46}$ As with actions under copyright law, for victims to pursue an action in tort substantial financial backing as well as time is required. In revenge pornography cases time for lengthy litigation is not a luxury victims have, given that once an image is uploaded onto the internet or disseminated in any way it can continue to spread at speed.

As will be demonstrated, the emergence of a specific offence to curb the 'disclosure of private sexual images' does little to solve the current shortcomings of the pre-existing laws. It serves as an addition to the array of tools that attempt to tackle hostility and violence against women online but fails to attack the underpinning attitudes towards women's privacy that exist beneath it. Whilst it is accepted that the law may have a symbolic value in outlining the distribution of private sexual images as explicitly criminal behaviour, ${ }^{47}$ the focus on 'revenge' narratives that underpinned the legislative process, and the likely operation of the law, does not offer the practical redress needed by victims of revenge pornography and other related offences, and instead reinforces the gendered

\footnotetext{
${ }^{45}$ [2002] Q.B. 195

${ }^{46}$ See above $\mathrm{n} 38$ for an explanation of limitations in respect of an action for 'breach of confidence' in revenge pornography cases.

${ }^{47}$ R Cotterrell The Sociology of Law' (Oxford: Oxford University Press, $2^{\text {nd }}$ edition, 1984).
} 
This article has been published in a revised form in Legal Studies, http://doi.org/10.1017/lst.2018.27. This version is published under a Creative Commons CC-BY-NC-ND. No commercial re-distribution or re-use allowed. Derivative works cannot be distributed. (C) copyright holder.

power relations of heterosexual socio-cultural scripts. It is not argued here that all wrongs and the harms that flow from them should be criminalised, certainly the proper contours of criminalisation require limitations to prevent, for example, the criminalisation of trivial wrongs. In the case of revenge pornography the disclosure of private sexual images, contrary to Section 33, clearly result in harms that cause psychological or other damage to a person's quality of life beyond that of mere trivialities, such as loss of employment and breach of privacy. ${ }^{48}$ Gillespie argues that a rationale for criminalising revenge pornography is to protect a person's sexual autonomy and identity likening the disclosure of private sexual images to the absence of consent in sexual offences. ${ }^{49}$ It will be explained below how the new law purports to protect women from the very attitudes it threatens to reinforce; heteronormative assumptions about femininity and women's sexuality long embedded in the criminal-legal construction of revenge. As we have seen, the primary distinguishing feature of the new offence is its focus on punishing the specific intent to cause distress through the circulation of private sexual photographs. However, the offence fails to take into consideration either how this intention is frequently gendered in the context of intimate relationships, or the harms it may cause beyond distress.

\section{A Dish Best Served Cold: Sexual Revenge and the Law}

\footnotetext{
${ }^{48}$ See A P Simester and A von Hirsch Crimes, Harms and Wrongs: On the Principles of Criminalisation (Hart Publishing, 2011)

${ }^{49}$ Gillespie, above $\mathrm{n} 1$.
} 
This article has been published in a revised form in Legal Studies, http://doi.org/10.1017/lst.2018.27. This version is published under a Creative Commons CC-BY-NC-ND. No commercial re-distribution or re-use allowed. Derivative works cannot be distributed. (C) copyright holder.

Discourses of revenge found in cases involving crimes of passion, where men have been excused for killing their adulterous wives, ${ }^{50}$ and how the criminal law has historically treated gendered revenge motives, assist us firstly in analysing to what extent socio-cultural revenge scripts underpin the new offence, and secondly in identifying how the problem of victim-blaming is likely to arise in order to establish mens rea. In the context of spousal homicide, a defendant's violent actions have been constructed as excusatory and justificatory ${ }^{51}$ under partial defences that reduced a charge of murder to manslaughter. Horder notes that the historical function of the partial defence of provocation was justificatory 'because it requires the defendants to explain their conduct, in part, by reference to the "moral warrant" that they believed the gravity of the provocation gave them for retaliating so violently in anger' ${ }^{52}$ In terms of the excusatory element, the defence does not operate to 'correct' the defendant's wrongful conduct; instead it sheds 'favourable moral light on what $\mathrm{D}$ did through a focus on the reasons that $\mathrm{D}$ committed that wrongdoing.' 53 The defence's focus on the victim's actions in such cases, and what she might have done to provoke the defendant, is often pivotal to the verdict. Whilst revenge is not an explicit component of the Section 33 offence, it is the way in which it is likely to operate in the courts that demands comparison with provocation.

The old law of provocation was set out in Section 3 of the Homicide Act 1957, reducing a charge of murder to manslaughter and in doing so removing

\footnotetext{
${ }^{50} \mathrm{~J}$ Horder and K Fitz-Gibbon 'When sexual infidelity triggers murder: examining the homicide law reform on judicial attitudes in sentencing' (2015) 74 Camb L J 307.

51 J Dressler 'Provocation: Partial Justification or Partial Excuse?' (1988) 51 Mod Law Rev 467.

52 J Horder Provocation and Responsibility (Oxford: Clarendon Press, 1992), p 112.

${ }^{53}$ J Horder Excusing Crime (Oxford: Oxford University Press, 2004) at p 8-9
} 
This article has been published in a revised form in Legal Studies, http://doi.org/10.1017/lst.2018.27. This version is published under a Creative Commons CC-BY-NC-ND. No commercial re-distribution or re-use allowed. Derivative works cannot be distributed. (C) copyright holder.

the mandatory life sentence associated with murder. ${ }^{54}$ In cases where the provocation defence was used to excuse the defendant's actions in 'crimes of passion ${ }^{55}$ it hinged on whether the victim's actions provoked the defendant to lose his or her self-control. Cases concerning the operation of the provocation plea evidence the way in which male sexual jealousy is regarded in criminallegal discourse as another 'natural' evolutionary supplement: a question of 'male sexual proprietariness'. ${ }^{56}$ In the case of $R v$ Suratan, $R v$ Humes and $R v$ Wilkinson (Attorney General's Reference No. 74, No. 95 and No. 118 of 2002), ${ }^{57}$ the appeal concerned the sentences imposed for manslaughter in a matrimonial or domestic setting, where a plea of provocation had been accepted, which were regarded as overly 'lenient' and therefore failed to 'reflect the seriousness of the offences' ${ }^{58}$ Sentences of between 2 and 7 years had been imposed upon the three men for what Howe describes as an 'annihilation of their female partners'. ${ }^{59}$ Such lenient sentences, handed down in instances where men kill women suspected of adultery, have served as evidence that the courts regard the

\footnotetext{
54 The requirements of the defence in Section 3 of the Homicide Act 1957 were as follows:

'Where on a charge of murder there is evidence on which the judge can find that the person charged was provoked (whether by things done or by things said or by both together) to lose his self-control, the question whether the provocation was enough to make a reasonable man do as he did shall be left to be determined by the jury; and in determining that question the jury shall take into account everything both done and said according to the effect which, in their opinion, it would have on a reasonable man.'

${ }^{55}$ Howe, above n 10.

${ }^{56}$ M I Wilson and M Daly 'Male Sexual Proprietariness and Violence Against Wives' (1996) 5 Current Directions in Psych Sci 2.

${ }^{57}$ [2002] EWCA 2982

58 [2002] EWCA 2982 at [6]

59 A Howe 'Provocation in crisis - Law's Passion at the Crossroads? New Directions for Feminist Strategists’' (2004) 21 Aus Feminist L J 1
} 
This article has been published in a revised form in Legal Studies, http://doi.org/10.1017/lst.2018.27. This version is published under a Creative Commons CC-BY-NC-ND. No commercial re-distribution or re-use allowed. Derivative works cannot be distributed. (C) copyright holder.

men as justifiably provoked..$^{60}$ The law of provocation primarily focused on the behaviour of the victim and what they did to cause the behaviour of the defendant.

It is accepted that revenge in relation to Section 33 and the partial defences of provocation and loss of control function in different ways. In the case of Section 33, the defendant's 'intention to cause distress' is central to establishing the offence itself in the courts, whereas revenge in the defence of provocation operates to reduce liability in cases of murder. However, the way revenge is operationalized in practice, in both offences, risks individualising violence against women, reimagining that violence as an act of revenge with justificatory or excusatory qualities that limit wrongfulness. In Section 33 the focus is on the motivations of the perpetrator instead of the impact on the victim and, like partial defences to homicide, its operation is also likely to be scaffolded around male proprietariness. It has the potential to bring to the table a discussion or at least, a consideration, of what the victim did to deserve this. Ultimately, both homicide and revenge pornography offences permit attempts to excuse or justify harmful behaviour by constructing it as anything but violence against women. The search for a rationale as to why the avenger might have sought to disclose private sexual images to cause distress allows for the possibility that victims risk being seen ultimately as still at fault: she got what she deserved.

As noted in the opening section of this article, revenge pornography has been constructed in popular discourse and in practice as a kind of contemporary 'crime of passion' through the narrative of the jilted sexual partner. It is

\footnotetext{
${ }^{60}$ S Edwards 'Provoking Her Own Demise: From Common Assault to Homicide', in J Hanmer and M Maynard (eds) Women, Violence and Social Control (London: Palgrave Macmillan Press, 1987).
} 
This article has been published in a revised form in Legal Studies, http://doi.org/10.1017/lst.2018.27. This version is published under a Creative Commons CC-BY-NC-ND. No commercial re-distribution or re-use allowed. Derivative works cannot be distributed. (C) copyright holder.

specifically a question of 'passion' that appears to govern the mens rea and thus the threshold for culpability in Section 33(1)(b). As Ledward and Agate have noted, in many Section 33 cases that have come before the courts to date evidence of intent is fairly obvious, ${ }^{61}$ but the necessity of the provision of evidence risks necessitating exploration of a rationale for sharing the image and thus examination of the victim's behaviour. Indeed, this may be entirely necessary for a successful prosecution. As the question of intent turns on malice rather than sexual gratification, and the Section 33 offence is not a sexual offence, the usual protections proffered to victims of sexual violence do not currently apply and serve only to exacerbate the potential problem of double victimisation. ${ }^{62}$ As we will demonstrate, media reports of these cases rarely shirk on the circumstantial details that led the perpetrator to share the image. The very fact that these details are available for press coverage suggests that precipitating factors are already being cross-examined in court. In addition, figures from the Crown Prosecution Service 2015-16 - with around 61\% of reported cases resulting in no further action - suggest that either there is insufficient evidence of specific intent, or that the victim has withdrawn support for action ${ }^{63}$. We surmise that one factor that might give rise to the latter is the problem of potential victim blaming, and the need for cross examination of precipitating factors that Section 33(1)(b) requires to prove intent.

\footnotetext{
${ }^{61}$ J Ledward and J Agate "'Revenge Porn" and Section 33: The Story so Far" (2017) 28 Ent L Rev 41.

${ }^{62}$ For a comparative study of how double victimisation operates in cases of rape, see K Soothill and S Walby 'Prosecuting the victim? A Study of the Reporting of Barristers' Comments in Rape Cases' (1993) 32 Howard J of C J 12.

${ }^{63} \mathrm{M}$ Ellis 'Anonymity in Revenge Pornography Cases' Lexology 12 September 2016, available at <http://www.lexology.com/library/detail.aspx?g=dfd1602c-5b3f-4798-966a-eb84f8733733> (accessed 15 June 2017).
} 
This article has been published in a revised form in Legal Studies, http://doi.org/10.1017/lst.2018.27. This version is published under a Creative Commons CC-BY-NC-ND. No commercial re-distribution or re-use allowed. Derivative works cannot be distributed. (C) copyright holder.

As Jacoby suggests, there are 'written and unwritten laws governing sexual relationships, which, because of their emotional nature, are generally treated as questions of passion rather than power'. ${ }^{64}$ Thus, it is perhaps no surprise that the operation of the law risks focusing on the 'passions' that stimulate a desire to cause distress. This significantly limits the circumstances in which a case is likely to come to trial to those involving clear evidence of intent, ${ }^{65}$ but more crucially also represents an attempt to transpose the rules of civility that have historically governed romantic relationships, both written and unwritten, to the digital age. This leads Jacoby to the rather controversial question: 'ought people who are bound together ... by emotionally binding ties of intimacy, be allowed to take revenge on each other in ways that would ordinarily be forbidden by law? ${ }^{66}$ Closer inspection of how revenge in the context of intimate relationships has been constructed in criminal-legal discourse in recent years not only aids our understanding of the legal context for the new offence, but provides clues as to why discussion within the legislative process and media reporting became dependent on retrogressive constructions of (predominantly) heterosexual relationships. As we will see, references to love, honour and injury pervade these cases, and - although there have been cases reported of female revenge porn perpetrators - demonstrate the particularly gendered qualities that haunt legal constructions of revenge.

An important development in the recent history of punishing crimes of passion is the supposed distinction between a 'loss of control' and revenge in

\footnotetext{
${ }^{64}$ S Jacoby Wild Justice: The Evolution of Revenge (London: Harper \& Row 1983) 184.

${ }^{65}$ McGlynn and Rackley, above $\mathrm{n} 2$.

${ }^{66}$ Jacoby, above n 65, at 223.
} 
This article has been published in a revised form in Legal Studies, http://doi.org/10.1017/lst.2018.27. This version is published under a Creative Commons CC-BY-NC-ND. No commercial re-distribution or re-use allowed. Derivative works cannot be distributed. (C) copyright holder.

partial defences to murder, outlined briefly in the previous section. Section 54(4) of the Coroners and Justice Act 2009 makes clear that: 'Subsection (1) does not apply if, in doing or being a party to the killing, D acted in a considered desire for revenge. ${ }^{67}$ What distinguishes a momentary loss of control and revenge in law is a sense that the injury is inflicted in a considered manner, aiming to 'right' a perceived 'wrong'. Nevertheless, in the case of $R v$ Clinton, Parker and Evans, ${ }^{68}$ this distinction appeared particularly flimsy, and the judgment hinged on the meaning of revenge. In each case brought to the attention of the appellate courts, a jilted husband killed his ex-wife after she had admitted to him that she had been having a relationship with another man. Despite the move to exclude sexual infidelity as a qualifying trigger in the partial defence of loss of control, the perpetrator may be treated sympathetically in the case of romantic relationships where it is assumed that the 'passion' governing violence in response to infidelity, sexual jealousy and 'crushed dreams', provided it is used to contextualise 'a sense of being seriously wronged by a thing said or done, ${ }^{69}$, provides the defendant with a justifiable sense of being wronged and excuse to use violence. . As Lord Judge averred in his ruling in Clinton: 'Relationship breakdown is always fraught with tension and difficulty, with the possibility of misunderstanding and the potential for apparently irrational fury'. ${ }^{70}$

That a 'special case' is made for revenge motivations in the breakdown of a romantic relationship in this judgment is revealing, and the implications of Clinton for cases involving spousal homicide have been the subject of multiple

\footnotetext{
${ }^{67}$ Section 54(4) Coroners and Justice Act 2009.

${ }^{68}$ Clinton, Parker and Evans, above n 11.

${ }^{69}$ Section 55(6)(b) Coroners and Justice Act 2009

${ }^{70}$ Clinton, Parker and Evans, above n 11 at [16].
} 
This article has been published in a revised form in Legal Studies, http://doi.org/10.1017/lst.2018.27. This version is published under a Creative Commons CC-BY-NC-ND. No commercial re-distribution or re-use allowed. Derivative works cannot be distributed. (C) copyright holder.

criticisms. $^{71}$ For our purposes, however, that vengeful motivations in the context of romantic relationships are treated as excusatory also has symbolic significance, and is potentially catastrophic for victims of revenge pornography. As Lord Judge goes on to argue in Clinton:

Experience over many generations has shown that, however it may become apparent, when it does, sexual infidelity has the potential to ... produce a completely unpredictable, and sometimes violent response ... [which] often stems from a sense of betrayal and heartbreak, and crushed dreams. ${ }^{72}$

This kind of language, used to describe the circumstances in which Section 54(4) does not apply, betrays judicial sentiments towards the anticipated gender roles taken in romantic relationships, and the sense that when 'passion' clouds judgement, it may be taken as an excusatory factor. This view of revenge - and perhaps the 'experience over generations' the judges refer to - also recalls the long history of possessive erotic love, in which the old 'male dream of symmetry', ${ }^{73}$ with man as the possessor and woman as exclusively possessed becomes central to the gendered constitution of revenge; where one's 'hotbloodedness' is considered a necessary precursor to the defence of erotic love, and a guard over one's manliness and virility. As Howe puts it, Clinton reveals that the "profoundly sexed early modern fiction of his possessory right over her [which] can be traced through centuries of case law still finds a place in

\footnotetext{
${ }^{71}$ See, for example, Horder and Fitzgibbons, above n 50; Howe, above n 10; K J Kesselring 'No Greater Provocation? Adultery and the Mitigation of Murder in English Law' (2015) 34 Law \& Hist Rev 199.

${ }^{72}$ Clinton, Parker and Evans, above n 11, at [16].

${ }^{73}$ N Naffine 'Possession: Erotic Love in the Law of Rape' (1994) 57 Mod L Rev 10.
} 
This article has been published in a revised form in Legal Studies, http://doi.org/10.1017/lst.2018.27. This version is published under a Creative Commons CC-BY-NC-ND. No commercial re-distribution or re-use allowed. Derivative works cannot be distributed. (C) copyright holder.

late modern and putatively egalitarian democracies'. ${ }^{74}$ While not all Section 33 cases involve suspected infidelity, as we will see, the cases reported in the press to date invariably do rest on sexual jealousy. Further, however, the analogy with Clinton and other cases of intimate partner homicide ultimately demonstrate the problem at the heart of the offence. While the specific intent requirement allows for the possibility that intent to cause distress might be manifested in a number of ways, it nevertheless implies that the victim must have done something that provoked the defendant to develop such an intent. We therefore retain a certain cynicism about the operation of the offence. Where the circumstances in which the perpetrator circulates an image are revealed, and while the victim can be cross-examined to provide a backstory that offers a rationale for distributing the image to cause distress, juror sentiments towards the 'rules' of romantic relationships may well govern trial outcomes.

\section{Wild Justice: Tracing Revenge in Media, Parliamentary and Policy Narratives on Revenge Pornography}

Motivations for revenge pornography have been central to media coverage of the offence. The importance of the media coverage of revenge pornography cannot be understated given that the term revenge pornography itself is media generated. ${ }^{75}$ Despite our concerns raised previously - that the offence focuses primarily on the motivation behind the act - the term 'revenge pornography' dominates headlines

\footnotetext{
${ }^{74}$ A Howe 'Enduring Fictions of Possession' (2012) 21 Griff L Rev 772 at 778.

${ }^{75}$ A Powell and N Henry Sexual Violence in the Digital Age (Basingstoke: Palgrave Macmillan), p 119.
} 
This article has been published in a revised form in Legal Studies, http://doi.org/10.1017/lst.2018.27. This version is published under a Creative Commons CC-BY-NC-ND. No commercial re-distribution or re-use allowed. Derivative works cannot be distributed. (C) copyright holder.

of stories about those victimised. For example, in April 2016 the Plymouth Herald published a story in which Shaun Kinsman posted 35 sexual images of his expartner online following their breakup in 'an act of revenge pornography., 76 Kinsman declared that he posted the images in 'revenge' when he was rejected by the victim and 'felt hurt'. This story reflects the typical revenge narrative of nonconsensual image distribution following a breakup outlined in the introduction. However, the article also provides details of the victim's supposed infidelity to the perpetrator, noting that the image was posted on Facebook 'giving the location of the town where she lived, her age and claims that she had cheated on him with her ex' ${ }^{77}$ By providing information about the victim's supposed infidelity, the readers of the news become the judges of whether the assailant should be excused for distributing the private intimate image without her consent. The questions posed to these moral arbiters concern whether the women's act of infidelity justifies or excuses the act of uploading the images, or whether the woman's rejection of Kinsman equates to an act worthy of revenge.

In the media reporting of Kinsman's case, the ways in which infidelity is presented as central to the story are two-fold. On the one hand, it reifies violence against women as a justifiable act of revenge; on the other, by focusing on what the victim did to provoke such treatment, it preserves the status of masculinity as a means of controlling or punishing women who dare to betray or leave their partners. In turn, this reproduces the myth of male proprietariness over the

\footnotetext{
${ }^{76} \mathrm{~J}$ Lewis 'Cornish Man Posted 35 Revenge Porn Pictures Online after Breaking up with Girlfriend' Plymouth Herald 24 April 2016, available at http://www.plymouthherald.co.uk/cornish-man-posted-35-revenge-porn-pictures/story-29166938detail/story.html (accessed 22 December 2016).

${ }^{77}$ Ibid.
} 
This article has been published in a revised form in Legal Studies, http://doi.org/10.1017/lst.2018.27. This version is published under a Creative Commons CC-BY-NC-ND. No commercial re-distribution or re-use allowed. Derivative works cannot be distributed. (C) copyright holder.

endings of romantic relationships, where men and only men can instigate separation. It is noted that Kinsman 'felt hurt' and revenge pornography was his means of getting 'one up on her' because of her supposed infidelity. ${ }^{78}$ Violence against women is repackaged as a story of infidelity, hurt and revenge. Similarly, in the case of Paul Deacon, ${ }^{79}$ the perpetrator undertook a course of violence against his ex-partner, yet the media narrative again references her alleged infidelity, noting how Deacon, during a confrontation at the victim's house, '[accused] her of seeing someone else', ${ }^{80}$ which essentially provides the same infidelity revenge context as seen in the case of Kinsman.

While media reporting of revenge pornography cases tends ultimately to condemn the practice, it is perhaps unsurprising that journalists cannot help but linger on precipitating factors for the offence, namely the behaviour of the victim, which suggests that the sexual history of victims is indeed being scrutinised in the courts. However, as we will demonstrate, this is not simply a problem of sensationalist reporting, since this factor is endemic to the debates surrounding criminalisation, and even CPS and sentencing guidance. In the Parliamentary debates about revenge pornography that led to the creation of the offence, the purpose it should serve and what it specifically aims to criminalise proved difficult to define, but it was at this stage that revenge motivations took centrestage as the primary target of the new offence. In the first Commons debate in

\footnotetext{
${ }^{78}$ Ibid.

${ }^{79}$ Paul Deacon was jailed for six months for attacking his ex-wife and then posting a topless photo of her on Facebook.

${ }^{80}$ T Burrows "'Your Wives Are Not Your Property": Judge Blasts Jilted Husbands Who Post Revenge Porn as He Jails a Thug Who Attacked His Ex and Then Posted a Topless Picture of Her on Facebook' Mail Online 20 October 2016, available at <http://www.dailymail.co.uk/ /article3856002/index.html> (accessed 1 November 2016).
} 
This article has been published in a revised form in Legal Studies, http://doi.org/10.1017/lst.2018.27. This version is published under a Creative Commons CC-BY-NC-ND. No commercial re-distribution or re-use allowed. Derivative works cannot be distributed. (C) copyright holder.

June 2014, Maria Miller MP, who raised the issue on behalf of a constituent who had been victimised, drew on the narrative of victims as ordinary women who have been in loving relationships .. [W] hen that relationship goes wrong, their partner's revenge is to post on the internet intimate pictures taken over the course of that relationship as well as distributing them to employers, families and friends. ${ }^{81}$

Miller was drawing on the specific experiences of her own constituent as a case study in this instance, and it should be noted that she was careful to avoid the use of any language which might responsibilise the victim, but initiating the debate by providing this specific story of revenge nevertheless shapes the terms of it, focusing the target for legislation around this quite specific narrative of romantic vengeance.

Miller went on to describe the internet as a kind of 'wild west', implying that despite the fact that the days of treating it as such are 'long gone and that freedom online is no longer unconditional', there is a sense that justice in this space is subject to the same pre-modern blood feuds that were curbed by civilised state-sanctioned retributive justice. Miller here could almost be drawing directly on Francis Bacon's famous essay, Of Revenge, from 1625, which describes revenge as a 'kind of wild justice, which the more man's nature runs to the more ought law to weed it out. ${ }^{82}$ The implication is that the internet, as Balkin alludes, is now a virtual environment 'which will reshape legal concepts like jurisdiction

\footnotetext{
${ }^{81}$ HC Deb 19 Jun 2014 c1369.

${ }^{82}$ F Bacon The Essays (Harmondsworth: Penguin 1985) p 72.
} 
This article has been published in a revised form in Legal Studies, http://doi.org/10.1017/lst.2018.27. This version is published under a Creative Commons CC-BY-NC-ND. No commercial re-distribution or re-use allowed. Derivative works cannot be distributed. (C) copyright holder.

and ownership'. ${ }^{83}$ In cyberspace, extra-legal 'wild justice' in the context of intimate relationships might be described as a new 'frontier' for legislators to colonise and overpower. The internet is constructed in these debates as a new and threatening terrain, in which blood revenge runs rampant and must be 'weeded out' with new legislative constraints.

When the Criminal Justice and Courts Bill 2015 eventually reached the House of Lords, the question of the purpose of the offence was again raised, and in particular whether it would constitute a sexual offence. The original Amendment tabled suggested that an offence would only be committed if the publisher intended that someone 'looking at the image did so for the purpose of obtaining sexual gratification'. ${ }^{84}$ Baroness Grender also chose to focus in her comments on the motive to 'sexually humiliate' in order to demonstrate that the libidinous properties of revenge must be at the forefront of the offence. Baroness Kennedy, however, urged the Lords to take greater care over the drafting:

It is important to draft widely without specifying the nature of the motivation. That is because it is always difficult to pin down motivation ... It is really an issue about consent: has a person consented to the disclosure of intimate photographs? It is not an issue of speculating what the motivations might be..$^{85}$

Nevertheless, Baroness Kennedy's plea for a refocus on consent met with little response. Baroness Morris returned almost immediately to the question of motive in her reply to Baroness Kennedy, and seemed to ignore the consequences of

\footnotetext{
${ }^{83} \mathrm{JM}$ Balkin and N. Kozlovski 'Introduction' in J M Balkin and others (eds), Cybercrime: Digital Cops in a Networked Environment (New York, NY: NYU Press, 2007) p 1-2.

${ }^{84}$ HL Deb 21 July 2014 col 970.

${ }^{85}$ Ibid col 973-4.
} 
This article has been published in a revised form in Legal Studies, http://doi.org/10.1017/lst.2018.27. This version is published under a Creative Commons CC-BY-NC-ND. No commercial re-distribution or re-use allowed. Derivative works cannot be distributed. (C) copyright holder.

harm, saying: '[r]evenge is a horrible and destructive motive generally'. But perhaps the most revealing statement in this debate came from Baroness Barker, who again put the onus on motivation to criminalise:

Our amendment tries to focus not on the definition of what is pornographic but on the act of revenge. That is why, in our amendment, we have concentrated on the initial posting of an image rather than the reproduction or the recommunication of it, because the act of revenge happens in the initial posting. ${ }^{86}$

While this amendment was, in the end, withdrawn, that the terms of the debate remained focused on the law's capacity to deter and suppress the motivation to seek revenge in the perpetrator is significant. This stymied from the very first the potential of the offence to capture a broader range of technology-facilitated sexual violence and the harms they may cause.

Since the law came into force, considerable media attention has been paid to the new offence, but it has not escaped critique. In 2016, scarcely a year after the law came into force, the Liberal Democrats tabled a series of amendments, suggesting that a low number of convictions might be remedied by reforming the law to mirror Scotland's, in which the specific intent requirement in Section 33(1)(b) is not present, and instead proof of mere recklessness as to causing 'fear, alarm or distress' will suffice. While we are cautious of the possibility that this amendment could lead to a slippage between 'sexting' and revenge pornography, and would not recommend that the Scottish model is followed, ${ }^{87}$ the amendment

\footnotetext{
${ }^{86}$ Ibid col 976.

${ }^{87}$ Section 2 of the Abusive Behaviour and Sexual Harm (Scotland) Act 2016 criminalises disclosing, or threatening to disclose, an intimate photograph or film, where a defendant intends to
} 
This article has been published in a revised form in Legal Studies, http://doi.org/10.1017/lst.2018.27. This version is published under a Creative Commons CC-BY-NC-ND. No commercial re-distribution or re-use allowed. Derivative works cannot be distributed. (C) copyright holder.

does at least consider a wider range of possible harms to victims. In addition, the possibility of granting anonymity to victims was considered in Parliament. However, the amendments were not moved, and in the House of Lords, Baroness Williams reiterated the importance of the offence being 'undiluted' from its original aim of punishing revenge:

This malicious intent - the revenge element of revenge porn, so to speak - is a key feature of the offence and we believe it would be wrong to dilute this by applying the offence to conduct that is the result of recklessness rather than a deliberately malicious act. ${ }^{88}$

As we see, in these more recent debates there is little discussion of countering the surface-scratching nature of the legal response to disclosure of private sexual images, and although it is reassuring to see a wider range of possible harms victims may experience signposted, the response fails to delve much beyond specific intent.

Guidance on prosecution and sentencing has also remained focused on this aspect of the offence. The Crown Prosecution Service (CPS) issued guidelines to prosecutors reiterating at least one of the purposes of the disclosure of private sexual imagery must be to cause 'humiliation or embarrassment ${ }^{89}$ to the victim to meet the threshold for prosecution. Indeed, the guidance document itself is specifically titled 'Revenge Pornography'. This language fails to deal adequately with the social and economic harms associated with revenge pornography that go

cause alarm of distress to the victim or is reckless as to whether or not alarm or distress will be caused to the victim. Such an approach could inadvertently criminalise young people who share images of other young people (commonly referred to as sexting).

${ }^{88}$ HL Deb 16 November 2016 c 1443.

${ }^{89}$ Crown Prosecution Service 'Revenge Pornography - Guidelines on prosecuting the offence of disclosing private sexual photographs and film' (2016) available at <http://www.cps.gov.uk/legal/p_to_r/revenge_pornography/> (accessed 16 May 2017). 
This article has been published in a revised form in Legal Studies, http://doi.org/10.1017/lst.2018.27. This version is published under a Creative Commons CC-BY-NC-ND. No commercial re-distribution or re-use allowed. Derivative works cannot be distributed. (C) copyright holder.

beyond humiliation or embarrassment, and instead reduces the harm to merely an emotional or psychological response. Certainly, McGlynn, Rackley and Houghton have asserted that revenge pornography should form part of a continuum of 'image-based sexual abuse ${ }^{90}$ in which a connection is laid bare between revenge pornography and other forms of sexual violence, which they argue share both characteristics and consequences.

The reductive language used in this guidance to describe the associated harms of Section 33 offences distinguishes the way the offence is understood and consequently, responded to. For example, the limited remedies available to victims of disclosure of private sexual images fail to acknowledge the range of harms suffered by victims, such as breach of privacy, loss of employment and harassment. Nowhere in the CPS guidance are any of these harms mentioned. As Mathen suggests, refocusing on the link between revenge and distress has a certain social currency, in that it 'evokes some of what society finds especially horrifying about such activity, ${ }^{91}$ and therefore possesses an expressive function, but of course, this link may not be consistent in all cases. Yet Vora notes that underlying legal frameworks concerning disclosure of private sexual images also exists a 'shadow taxonomy' ${ }^{92}$ that minimises or trivializes the amount and types of harms experienced by victims, such as the "violation of fundamental rights to sexual autonomy, integrity and sexual expression' together with 'physical and mental illness'. 93 The result of this 'shadow taxonomy' is to 'deny victims an

\footnotetext{
${ }^{90}$ McGlynn, Rackley and Houghton 'Beyond 'Revenge Porn': The Continuum of Image-Based Sexual Abuse' (2017) 25 FLS 25.

${ }^{91}$ C Mathen 'Crowdsourcing Sexual Objectification' (2014) 3 Laws 529, 531.

${ }^{92}$ A Vora 'Into the Shadows: Examining Judicial Language in Revenge Porn Cases' (2017) 18 Geo J Gender \& L 229.

${ }^{93}$ McGlynn and Rackley, above $\mathrm{n} 2$.
} 
This article has been published in a revised form in Legal Studies, http://doi.org/10.1017/lst.2018.27. This version is published under a Creative Commons CC-BY-NC-ND. No commercial re-distribution or re-use allowed. Derivative works cannot be distributed. (C) copyright holder.

effective remedy, ${ }^{94}$ By failing to acknowledge the range of harms associated with disclosure of private sexual images, 'effective' remedies such as takedown orders or compensation for loss of employment are absent from discussion. Whilst Vora's work centres on the judicial language used in the courts, the same can be said for the language used in legal and policy debates elsewhere, and indeed, this is what we argue here - that the trivialisation or even disregard for the broader harms associated with revenge pornography go little way to improving current legal remedies.

More recently, the Sentencing Council initiated a consultation process in England and Wales over a set of draft guidelines for use in Section 33 cases. The proposed guidelines argue for a two-step process, whereby sentencing range is determined first on culpability factors, and secondly on the level of harm caused. Step one appears to address the question that there may be a spectrum of motivations. It draws on the distinction between 'hot' and 'cold-blooded' revenge to determine the level of culpability, differentiating between offences which are essentially 'pre-meditated', where there is a degree of 'significant planning and/or [resembles a] sophisticated offence' (cold-blooded), and offences where there is 'little or no planning' (hot-blooded). Whilst the importance of reflecting comparative blameworthiness in sentencing is acknowledged there is a risk here that disclosure of private sexual images might more easily be excused and/or justified, at least partially, if significant evidence is found that revenge was borne out of sudden and fleeting bouts of passion/fury. In addition, it is our contention that it is much more likely that cases in which culpability falls into Category $\mathrm{C}-$

\footnotetext{
${ }^{94}$ Vora, above n 92.
} 
This article has been published in a revised form in Legal Studies, http://doi.org/10.1017/lst.2018.27. This version is published under a Creative Commons CC-BY-NC-ND. No commercial re-distribution or re-use allowed. Derivative works cannot be distributed. (C) copyright holder.

where there is neither significant planning nor 'an intention to cause maximum distress' (as signposted in Category A) - would likely not be prosecuted at all due to insufficient evidence of specific intent

Step two of the draft guidelines highlight that sentencing should also consider the level of harm experienced by the victim. Whilst the move away from an exclusive focus on motivations is welcome, and whilst the Council does make an effort to address some of the harms suffered by victims, they are nevertheless extremely limited as a result of the centrality of the distress element to the offence. McGlynn et al have urged that revenge pornography be understood alongside other forms of sexual abuse in order that the harms it induces be better acknowledged and understood. ${ }^{95}$ When comparing the proposed sentencing guidelines to the sentencing guidelines for sexual offences, many of the harms associated with the latter are relevant here, such as 'severe psychological or physical harm,' 'additional degradation/humiliation' and 'violence or threats of violence'. ${ }^{96}$ However, the Section 33 guidelines barely touch on these. Category 1 - the highest level of harm - is limited to when there is 'very serious distress caused to the victim', harm where the 'victim is particularly vulnerable' and where the 'offence has considerable practical impact on the victim. ${ }^{97}$

There is also a considerable slippage between the terms 'distress' and 'harm' that runs throughout the guidelines, and in places the terms are used

\footnotetext{
${ }^{95}$ McGlynn, Rackley and Houghton, above n 90.

${ }^{96}$ Sentencing Council, Sexual Offences Definitive Guidelines (2013) available at $<$ http://www.sentencingcouncil.org.uk/wpcontent/uploads/Final_Sexual_Offences_Definitive_Guideline_content_web1.pdf> (accessed 2 June 2017).

${ }^{97}$ See above, n 98.
} 
This article has been published in a revised form in Legal Studies, http://doi.org/10.1017/lst.2018.27. This version is published under a Creative Commons CC-BY-NC-ND. No commercial re-distribution or re-use allowed. Derivative works cannot be distributed. (C) copyright holder.

interchangeably. While step two does take into account the fact that the harms of revenge porn are not limited to distress, step one restricts the intent encompassed under high culpability to conduct intended to cause distress. As the psychological literature reveals, the object of revenge pursuits is not always primarily to cause distress; indeed, this may well be a secondary or oblique intent. Section 33(8) of the Act states that:

a person charged with an offence under this section is not to be taken to have distributed a photograph or film with the intention of causing distress merely because that was a natural and probable consequence of the disclosure.

While possibly present to prevent the mens rea of the offence being diluted to mere recklessness, circumstances in which the offender does indeed intend principally to cause the victim harm - such as forwarding a private sexual image to her boss, with the intent of having her dismissed - either may not be caught by the offence or, at sentencing, will still not be regarded as possessing a high degree of culpability, since distress is not the direct intent. However, Gillespie, whilst noting the uncertainty of the wording within the section, suggests that it is more likely to relate to 'legitimate disclosures' that, whilst could result in 'distress' should not be captured by the act. ${ }^{98} \mathrm{~A}$ third question of concern regarding step 2 is how 'distress' might be measured for sentencing purposes. What evidence would need to be presented, and by whom? And is it realistic to presume that judges will agree that the level of harm constitutes Category 1

${ }^{98}$ See Gillespie, above $\mathrm{n} 1$ for a detailed discussion about Section 33(8). 
This article has been published in a revised form in Legal Studies, http://doi.org/10.1017/lst.2018.27. This version is published under a Creative Commons CC-BY-NC-ND. No commercial re-distribution or re-use allowed. Derivative works cannot be distributed. (C) copyright holder.

('serious types of harm'), when the defendant is considered to have a low degree of culpability?

The effect of public discourse and legislative focus operates to minimise the gendered nature of the harms that result from revenge pornography, and the terminology used throughout the CPS guidelines, draft sentencing guidelines and parliamentary debates signals a failure to 'appreciate the scale of the problem'. ${ }^{99}$ Whilst the positives in not being overly prescriptive in outlining a number of specific harms or scenarios are acknowledged (therefore not overly restrictive), the guidelines also assume that those using them will be able to consider and understand the nature and impact of the harms caused to victims and be able to adequately judge the level of harm and, indeed, 'distress'. It is notable that the example scenario provided in the guidelines (Case Study C) ${ }^{100}$ is precisely the paradigmatic revenge pornography case we outlined in the introduction. Thus, we are left with a sense that the facts of a case are likely to be 'measured up' against this paradigmatic scenario. With that said, if being overly prescriptive was really an issue surely this would be equally true in the sentencing guidelines for rape. Ultimately, both the Section 33 offence and the sentencing guidelines remain shackled primarily to punishing revenge motivations rather than acknowledging and remedying harms caused to victims. Until this is appreciated in prosecution and sentencing policy, and the offence itself is reformed to combat this, there will be limited success in resolving the deep-seated cultural issues associated with violence against women that underpin disclosure of private sexual images.

\footnotetext{
${ }^{99}$ McGlynn Rackley and Houghton, above n 90 at 14.

${ }^{100}$ See above, n 98 at 33.
} 
This article has been published in a revised form in Legal Studies, http://doi.org/10.1017/lst.2018.27. This version is published under a Creative Commons CC-BY-NC-ND. No commercial re-distribution or re-use allowed. Derivative works cannot be distributed. (C) copyright holder.

\section{Conclusion}

The House of Lords Communication Committee, which reports on social media offences, recommended that disclosure of private sexual images was already wellcovered by existing 'private laws' ${ }^{101}$ previously discussed within this article. Therefore, the only justification for the new offence is that it allows a victim to take retributive action and report, with the express goal of punishing for wrongdoing. Criminal justice intervention does not resolve any of the harms suffered by victims, given that the intervention provides no take-down solution of images automatically proffered in response to a successful prosecution, nor the ability to seek compensatory measures for, as an example, employment lost as a result of reputational damage. Practically, these are measures that would provide some redress to the victim of revenge pornography. The new offence predominantly focuses on the motivation behind the offence rather than the harm it causes the victim. The pursuit of revenge, it seems, is still as ripe a target for criminal-legal suppression now via Section 33, as it was then for crimes of passion. While the letter of the law makes no reference to revenge, for Section 33(b) to be proven it is likely to be difficult for a prosecution to avoid reference to the victim's actions. This exposes the problem at the heart of the offence. Despite its attempts to explicitly avoid 'revenge pornography', the specific intent requirement invites discussion of revenge motivations and precipitating factors for them in by the back door. We agree, however, with Gillespie that a strict liability offence is going too far, and thus, one further recommendation would be the

${ }^{101}$ Communications Committee, Social Media and Criminal Offences (HL 2014 -15, 37) para 13. 
This article has been published in a revised form in Legal Studies, http://doi.org/10.1017/lst.2018.27. This version is published under a Creative Commons CC-BY-NC-ND. No commercial re-distribution or re-use allowed. Derivative works cannot be distributed. (C) copyright holder.

removal of the specific intent requirement and instead a reliance on Section 8 Criminal Justice Act 1967, which refers to intent being determined 'by reference to all the evidence'. ${ }^{102}$ However, one caveat we would suggest would be that such evidence should not include the victim's sexual history and instead redirect focus on the effects of the disclosure on the victim (who should be permitted anonymity). Further, whilst there may be no place for a categorical approach in a reformed offence in terms of 'harms', perhaps the sentencing guidelines, had more care been taken, could offer greater acknowledgement of the harms as guidance and more solutions to the real harms associated with Section 33 offences, and address the same (take down orders, anonymity, financial redress to the victim (loss of job), restriction of victims sexual history). There are currently no reported cases under Section 33 in England and Wales. Thus, it is difficult to tell to what extent the cross-examination of the victim's behaviour impact on the sentence imposed or how the question of revenge is discussed in court. With this said, revenge dominates legal, policy and media discourse on revenge pornography that operates to redirect debate and legislative responses away from recognised acts of violence against women and towards a condemnation of female sexuality.

It is particularly disappointing to see that the question of anonymity was sidestepped in discussion of reform of the law, and we echo McGlynn and Rackley ${ }^{103}$ in recommending that this should be a primary consideration for legislators. In addition, very recently, the Ministry of Justice rejected calls to ban cross-examining victims on their sexual history in cases of rape, even if only in

\footnotetext{
${ }^{102}$ Gillespie, above $\mathrm{n} 1$.

${ }^{103}$ McGlynn and Rackley, above n 2, at 24.
} 
This article has been published in a revised form in Legal Studies, http://doi.org/10.1017/lst.2018.27. This version is published under a Creative Commons CC-BY-NC-ND. No commercial re-distribution or re-use allowed. Derivative works cannot be distributed. (C) copyright holder.

exceptional circumstances. ${ }^{104} \mathrm{We}$ would recommend that CPS guidance on Section 33 should be amended to not only remove any mention of 'revenge pornography', but in addition, should make clear that defence lawyers should not ordinarily cross-examine victims or, indeed, the perpetrator about their sexual history. While we believe that a high threshold for proving intention should be maintained, and do not recommend following the Scottish model, explicitly ruling it out would go some way to reducing secondary victimisation, and redirect the jury's attention squarely on the perpetrator's actions.

The paradigmatic narrative of revenge pornography looms large over the policy, legal and tabloid reporting of the offence, and as we have shown, relies on providing context for the act of revenge that either aims to mitigate the harm the victim suffered, or implicitly justify the 'need' for revenge as a recourse to infidelity or perceived wrongdoing on the part of the victim. However, the wider question this article has posed is whether revenge pornography, and the desire to criminalise it, would exist as a cultural phenomenon were women's sexual agency not considered a provocation deserving of revenge, or the basis for their condemnation. Merely criminalising intention to cause distress in revenge pornography as though it is a 'natural' and universal urge to be suppressed, just as was the case in 'crimes of passion', does little to overturn these heavily gendered dynamics and stereotypes, and instead reinforces and repeats age-old heteropatriarchal scripts that demand the sexual deviations of women, ultimately, cannot go unpunished.

\footnotetext{
${ }^{104}$ See Ministry of Justice, Limiting the Use of Complainants' Sexual History in Sexual Offence Cases, CM 9547.
} 